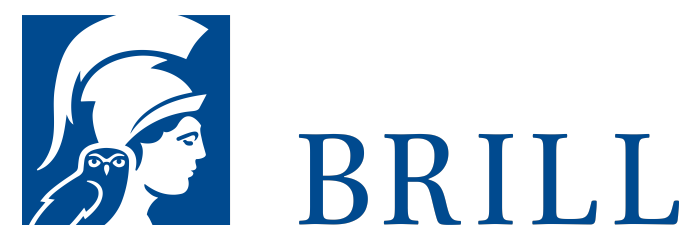

\title{
Radical Life Extension
}

An Ethical Analysis

Author: Tobias Hainz

Radical life extension is the direct and intentional extension of the maximum human life span through hypothetical biotechnologies. Although no such technologies do currently exist, it is imperative to analyze whether they should be developed because they could have considerable effects on individuals and societal structures. This book provides a comprehensive ethical analysis of radical life extension by investigating its possible influence on human welfare. Effects resulting from the actions of isolated individuals, such as the satisfaction or frustration of certain desires, are taken into account as well as collective effects, such as an increased trend towards overpopulation. Topics that are not directly related to human welfare are covered as well, for example, human nature and human dignity, the right to life, and the relationship between aging and the meaning of life. The book concludes with an outline of policy recommendations for future research on life extension technologies.

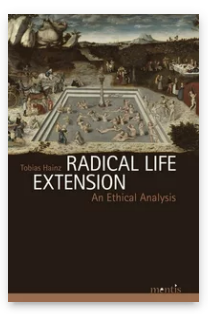

Pages: 346

Seiten

Language:

German

Subjects:

General,

Philosophy

Publisher: Brill | mentis

E-Book (PDF)

Released online:

19 Sep 2014

ISBN: $978-3^{-}$

95743-994-9

List price

Paperback

Publication date:

19 Sep 2014

ISBN: 978-3-

89785-493-2

List price 
For more information see brill.com

Order information: Order online at brill.com +44330 333 0049 | customerservices@brill.com Submission information: brill.com/authors

Titles published by Brill | Fink, Brill | mentis or Brill | Schöningh: +49(o)715413279216| brill@brocom.de 